\title{
MODEL PEDAGOGIK MULTILITERASI DALAM MENGEMBANGKAN KETERAMPILAN BERPIKIR ABAD KE-21
}

\author{
Pupun Nuryani $^{1}$, Yunus Abidin ${ }^{2}$, Yusuf Tri Herlambang ${ }^{3}$ \\ Universitas Pendidikan Indonesia
}

\begin{abstract}
The problem in this study is the low ability and thinking skills of 21st century Indonesian education, especially the critical thinking skills and problem solving. This is caused by several factors, one of the main factors is, learning that has not been oriented to the development of 21 st century thinking skills and still only focuses on achieving partial-textual knowledge and not on integrative-contextual understanding of the knowledge learned. In line with this, efforts are needed to improve the thinking skills of Indonesian education people. These efforts must be initiated by engineering an appropriate and targeted education model, one of which is the Pedagogic Multiliteration. This research was conducted using a mixture of exploratory type research methods. The subjects of this study are elementary school students in all regions of Indonesia who will be chosen purposively. Research Data will be collected using multi-instrument Research data will be processed using qualitative data processing techniques and quantitative data processing techniques with statistical tests. The results of this study prove that the implementation of multiliteration pedagogical models has been shown to be better in improving student's critical thinking skills and problem solving when compared to the ongoing model that is usually used in schools. This indicates that the multiliteration pedagogical model is better able to improve student's critical thinking skills and problem solving at the elementary school level effectively in various fields of study taught compared to the ongoing model that is usually used in elementary schools.
\end{abstract}

Keyword: Multiliteration Pedagogy, Thinking skills, Students Elementary School

\begin{abstract}
Abstrak: Masalah dalam penelitian ini adalah rendahnya kemampuan dan keterampilan berpikir insan-insan pendidikan Indonesia abad ke-21, khususnya ketermapilan berpikir berpikir kritis dan problem solving. Hal tersebut disebabkan oleh beberapa faktor, salah satu faktor utama ialah, pembelajaran yang belum diorientasikan pada pengembangan keterampilan berpikir abad ke-21 dan masih hanya berfokus pada pencapaian pengetahuan secara parsial-tekstual dan bukan pada pemahaman secara integratif-kontekstual terhadap pengetahuan yang dipelajari. Sejalan dengan hal tersebut, diperlukan upaya meningkatkan keterampilan berpikir insan-insan pendidikan Indonesia. Upaya tersebut harus diawali dengan merekayasa model pendidikan yang tepat guna dan tepat sasaran, salah satunya ialah Pedagogik Multiliterasi. Penelitian ini dilaksanakan dengan menggunakan metode penelitian campuran tipe eksploratori. Subjek penelitian ini adalah siswa sekolah dasar di seluruh wilayah Indonesia yang akan dipilih secara purposif. Data Penelitian akan dikumpulkan dengan menggunakan multiinstrumen Data hasil penelitian akan diolah dengan menggunakan teknik pengolahan data kualitatif dan teknik pengolahan data kuantitatif dengan uji statistika. Hasil penelitian ini membuktikan bahwa implementasi model pedagogik multiliterasi telah terbukti lebih baik dalam meningkatkan kemampuan berpikir kritis dan problem solving siswa jika dibandingkan dengan model terlangsung yang
\end{abstract}

\footnotetext{
' Universitas Pendidikan Indanesia, Email: Pupun.nuгyani国upi.edu

${ }^{2}$ Universitas Pendidikan Indanesia, Email: yunusabidin回upi.edu

${ }^{3}$ Universitas Pendidikan Indanesia, Email: yusufth回upi.edu
} 
biasanya digunakan di sekolah. Hal ini menandakan bahwa model pedagogik multiliterasi lebih mampu meningkatkan kemampuan berpikir kritis dan problem solving siswa pada jenjang sekolah dasar secara efektif pada berbagai bidang kajian yang diajarkan dibandingkan dengan model terlangsung yang biasanya digunakan di sekolah dasar.

Kata Kunci: Pedagogik Multiliterasi, keterampilan berpikir, Siswa Sekolah Dasar

\section{PENDAHULUAN}

Abad ke-21 merupakan abad perubahan zaman yang ditandai dengan adanya kemajuan ilmu pengetahuan dan teknologi yang berimplikasi pada perubahan kehidupan yang semakin kompleks. Hal ini berimbas pula pada terbangunnya suatu tatanan kehidupan yang semakin kompetitif, sehingga perlu adanya pengembangan mutu sumber daya manusia secara utuh, baik kemampuan atau keterampilan yang dimiliki, guna meningkatkan daya saing yang kuat dan unggul untuk berkompetisi dalam dunia tanpa batas. Selain dari itu, peningkatan sumber daya manusia juga perlu diorientasikan pada upaya untuk membangun kesadaran kritis tentang kehidupan yang perlu disandarkan pada nilai-nilai kebudayaan (partikular maupun universal). Hal ini sesuai dengan pendapat Freire (2008) yang mengungkapkan bahwa suatu zaman selalu ditandai dengan kompleksitas persoalan, gagasan, konsep, harapan, dan tantangan dalam interaksi dialektis untuk merumuskan penyelesaiannya.

Berkaitan dengan hal di atas, upaya peningkatan sumber daya manusia dapat dilakukan pada sektor pendidikan sebagai upaya dalam membangun sebuah peradaban baru dalam dinamika kehidupan yang semakin maju. Hal tersebut karena proses pendidikan adalah bagian dari perubahan sosial (Tilaar, 2012, hlm. 92). Pendidikan harus mampu meningkatkan mutu manusia yang memiliki daya kritis, kreatif, futuristis dan berkarakter agar memiliki kemampuan adaptif untuk dapat menjalani hidup dan berkehidupan dalam persaingan global, dan bukan melahirkan manusia yang bisu tanpa daya kritis dan cenderung pasif-reseptif serta gagap budaya. Oleh sebab itu pendidikan sebaiknya mampu membangun sikap kritis yang bertanggung jawab, bukan kritis yang dogmatis-ideologis (Risakotta dalam Azzet, 2011, hlm. 73)). Berdasarkan hal tersebut maka dapat dipahami bahwa sumber daya manusia yang bermutu hanya dapat dicapai melalui pendidikan yang berkualitas (Tilaar, 2009).

Selain dari penjelasan di atas, aspek sosio-kultural penting dipahami sebagai bagian prinsip dari pengembangan pendidikan yang harus senantiasa didasarkan pada nilai kebudayaan. Hal ini sesuai dengan pendapat Dewantara (2011) yang mengungkapkan bahwa "kebudayaan tidak dapat dipisahkan dari pendidikan bahkan kebudayaan merupakan alas atau dasar pendidikan". Dengan kata lain pendidikan dimaknai sebagai usaha manusia untuk membina kepribadiannya sesuai dengan nilai-nilai di dalam masyarakat dan kebudayaan (Hasbullah, 2008, hlm. 1). Senada dengan pendapat tersebut, Tilaar (2012) berpendapat bahwa pendidikan adalah suatu proses manusiawi berupa tindakan komunikatif dialogis transformatif, antara peserta didik dan pendidik yang bertujuan etis, yaitu menambah pengembangan kepribadian peserta didik seutuhnya dalam konteks lingkungan alamiah dan kebudayaan yang berkeadaban.

Berdasarkan penjelasan di atas, pendidikan Indonesia belum berorientasi pada upaya dalam melahirkan insan pendidikan yang memiliki kemampuan dan keterampilan abad ke-21 tersebut. Hal ini dibuktikan oleh studi PIRLS (2011), 
PISA (2012), dan OECD (2013), yang menunjukkan rendahnya kemampuan dan keterampilan siswa Indonesia. Hal ini dipertegas pula oleh Tilaar (2015) yang mengungkapkan bahwa Kualitas sumber daya manusia Indonesia terkenal rendah karena pendidikan yang tidak mencukupi dan penguasaan yang minim. Selain dari kondisi tersebut, pendidikan saat ini juga telah beralih fungsi yang seharusnya menjadi sarana dalam menginternalisasikan nilai-nilai budaya, menjadi sarana dalam melahirkan robotrobot yang hidup secara mekanistis dan individual, bukan manusia-manusia yang bermoral dan hidup secara kolektif dalam ruang kehidupan yang penuh kedambaan dengan nilai keberadaban. Dengan kata lain bahwa Pendidikan telah menyimpang dari hakikatnya yang seharusnya mampu melahirkan manusia-manusia yang memiliki sikap adaptif dalam kehidupan, justru sebaliknya hanya melahirkan manusia-manusia yang gagap budaya dalam menjalani kehidupannya. Itu artinya bahwa pendidikan telah mengalienasi peserta didik untuk hidup dan berkehidupan dalam dunianya yang penuh dengan nilai-nilai luhur (partikular/ universal). Menyikapi kondisi ini Tilaar (2002, hlm. 67) berpendapat bahwa pendidikan telah dicabik dari keberadaannya sebagai bagian yang terintegrasi dengan kebudayaannya. Pendidikan seakan menjadi belenggu pengikat kebebasan manusia.

Berdasarkan pada kenyataan di atas, upaya dalam meningkatkan kualitas pendidikan yang mampu melahirkan insan-insan Indonesia dengan kompetensi Abad ke-21, hendaknya dilakukan sedini mungkin dengan melakukan revitalisasi pendidikan, agar pendidikan mampu menjalankan perannya untuk melahirkan insan-insan pendidikan yang memiliki kompetensi abad-21 tersebut. Selain itu pendidikan harus menjadi sebuah sarana dalam membangun peradaban yang didasarkan pada nilai-nilai kebudayaan bangsa Indonesia. Hal ini sejalan dengan pendapat Al Muchtar (2001, hlm. 296) yang mengungkapkan bahwa "Menempatkan pendidikan sebagai aspek kebudayaan serta mencari alternatif pemecahannya atas dasar berpikir analitik kebudayaan, merupakan suatu keharusan, sebagai jawaban atas tuntutan nilai intrinsik pendidikan itu sebagai bagian dari kebudayaan".

Berdasarkan hal di atas, kondisi ini menjadi dasar dalam upaya pembenahan secara sistemik dalam konteks pendidikan, baik dalam aspek sekolah, guru, kurikulum, KBM maupun dalam hubungannya dengan aspek pendukung lainnya. Upaya peningkatan kualitas pendidikan dapat dilakukan melalui penerapan pedagogik multiliterasi. Pedagogik multiliterasi merupakan dasar penyelenggaraan pendidikan dan pembelajaran yang berorientasi pada upaya dalam membangun wawasan dan pemahaman siswa agar mereka mampu mengembangkan keterampilan berpikir (kritis, kreatif, problem solving dan metakognisi) yang didasarkan dan dikembangkan melalui latar belakang sosial budaya (Cope and Kalantzis, 2005; Herlambang 2018), sehingga bertitik tolak pada hal tersebut, peneliti tertarik untuk mengimplementasikan Model Pedagogik Multiliterasi yang merupakan konsep pendidikan dan pendekatan belajar yang dikembangkan berdasarkan kesadaran dan pengakuan atas keberagaman dan kompleksitas perspektif budaya siswa sebagai upaya dalam mengembangkan insan Indonesia yang futuristik dan cemerlang.

\section{METODOLOGI PENELITIAN}

Metode penelitian yang digunakan dalam penelitian ini adalah penelitian mixed methods. Penelitian mixed methods sendiri dapat dibagi menjadi empat, yakni tipe embedded, explanatory, exploratory, dan triangulation (Cresswell, 2007, hlm. 62-79). Dari keempat tipe desain penelitian di atas, tipe penelitian yang akan digunakan adalah tipe exploratory. 
Pemilihan tipe eksploratori sejalan dengan tahapan penelitian yang dilaksanakan yakni penelitian ini diawali dengan kegiatan penelitian kualitatif yang ditujukan untuk mengeksplorasi proses pedagogik multiliterasi di sekolah, kebutuhan siswa dan guru tentang model pedagogik multiliterasi, dan merancang bangun pola-pola pedagogik multiliterasi. Hasil kegiatan ini adalah pola pedagogik multiliterasi yang masih bersifat model hipotetis. Tahap kedua penelitian adalah menguji model hipotetis tersebut melalui kegiatan penelitian eksperimen (kuantitatif). Penelitian eksperimen ini akan memberikan keputusan tentang keberterimaan atau tidaknya model hipotetis yang dikembangkan untuk diterapkan di sekolah dasar secara luas.

Subjek penelitian ditentukan dengan cara purposif sampling. Untuk studi penjajakan ditetapkan beberapa sekolah dasar di wilayah Provinsi Jawa Barat. Wilayah dipilih secara purposif meliputi Kabupaten Pangandaran, Kota Tasikmalaya, Kota Bandung, Kabupaten Bandung, Kabupaten Cirebon, dan Kabupaten Bogor. Kelas uji eksperimen terbatas akan ditetapkan siswa kelas V SD pada tiga sekolah yang akan dipilih secara acak. Untuk uji validasi akan dipilih siswa kelas V SD yang berasal dari 6 sekolah dari tiga wilayah kabupaten/kota yang berbeda. Penentuan lokasi sekolah akan dilakukan secara purposif dengan pertimbangan lokasi sekolah dan kemampuan akademis siswanya. Berdasarkan hal tersebut jumlah sampel penelitian ini adalah sejumlah 288 orang siswa yang dibagi ke dalam dua kelas yakni kelas eksperimen sebanyak 144 siswa dan kelas kontrol sebanyak 144 siswa.

Instrumen yang digunakan untuk mengumpulkan data penelitian ini adalah (1) kuesioner semiterstruktur untuk mengumpulkan data studi kebutuhan (2) pedoman wawancara semi terstruktur untuk mengumpulkan data respons guru tentang model Pedagogik Multiliterasi (3) tes untuk mengukur kemampuan berpikir kritis dan problem solving siswa, (4) penilaian proses berbentuk skoring rubrik untuk mengukur aktivitas siswa, (5) catatan lapangan untuk mengumpulkan data hasil kegiatan observasi, (6) panduan penilaian proses pembelajaran pedagogik multiliterasi, dan (7) dokumentasi untuk mengumpulkan data proses pelaksanaan penelitian.

Berdasarkan jenis instrumen yang digunakan, penelitian ini akan menghasilkan dua jenis data yakni data kualitatif dan data kuantitatif. Data kualitatif yang dihasilkan pada dasarnya berupa data studi penelusuran. Data tersebut adalah data hasil (1) gambaran proses pembelajaran di sekolah; (2) gambaran kebutuhan guru dan siswa terhadap model pedagogik multiliterasi; dan (3) gambaran pola-pola pedagogik multiliterasi yang dikembangkan. Data kualitatif tersebut akan dianalisis dengan menggunakan teknik induktif dengan tahapan (1) mengumpulkan, membaca, dan mempelajari data melalui penandaan katakata kunci dan gagasan yang ada dalam data; (2) klasifikasi data berdasarkan tematema data; (3) menuliskan 'model' yang ditemukan; dan (4) memaknai data yang dihasilkan.

Data kuantitatif yang dihasilkan dalam penelitian ini adalah data yang berhubungan dengan hipotesis yang diajukan yakni kemampuan berpikir kritis, dan problem solving. Data ini akan dianalisis dengan menggunakan metode statistik yaitu uji beda ( $\mathrm{t}$ ) dengan bantuan SPSS versi 20, sementara untuk analisis adanya interaksi model digunakan metode statistik yaitu analisis Anova dengan bantuan SPSS versi 18.

\section{HASIL PENELITIAN DAN PEMBAHASAN}

\section{Uji Hipotesis Pertama}

Hipotesis pertama yang diuji dalam penelitian ini adalah model pedagogik multiliterasi berpengaruh secara signifikan terhadap kemampuan berpikir kritis dan 
problem solving pada siswa kelas eksperimen. Berdasarkan hasil uji $t$ terhadap perbandingan nilai kemampuan berpikir kritis dan problem di kelas eksperimen diperoleh data sebagai berikut.

Tabel 4.1

Hasil Uji Perbandingan Nilai Kemampuan Berpikir Kritis dan Problem solving antara Pretes dan Postes Kelas Eksperimen

\begin{tabular}{|c|c|c|c|}
\hline & Pair 1 \\
\hline & & & $\begin{array}{c}\text { Postes Eksperimen } \\
\text { - Pretes } \\
\text { Eksperimen }\end{array}$ \\
\hline \multirow{6}{*}{$\begin{array}{l}\text { Paired } \\
\text { Differen } \\
\text { ces }\end{array}$} & \multicolumn{2}{|l|}{ Mean } & 20,50694 \\
\hline & \multicolumn{2}{|l|}{ Std. Deviation } & 12,42206 \\
\hline & \multicolumn{2}{|l|}{ Std. Error Mean } & 1,03517 \\
\hline & $95 \%$ & Lowe & 18,46073 \\
\hline & Confidence & & \\
\hline & $\begin{array}{l}\text { Interval of the } \\
\text { Difference }\end{array}$ & $\begin{array}{l}\text { Uppe } \\
\mathrm{r}\end{array}$ & 22,55316 \\
\hline & 19,810 \\
\hline \multirow{2}{*}{\multicolumn{3}{|c|}{$\begin{array}{l}\text { Df } \\
\text { Sig. (2-tailed) }\end{array}$}} & 143 \\
\hline & & Sig. (2-tailed) & 000 \\
\hline
\end{tabular}

Berdasarkan tabel di atas dapat dikemukakan bahwa nilai t hitung sebesar 19,81. Besaran nilai Sig. (2-tailed) adalah 0,00. Ternyata nilai Sig. (2-tailed) lebih kecil dibanding taraf signifikasi (alfa) 0,05 . Hal ini berarti terdapat perbedaan antara nilai kemampuan berpikir kritis dan problem solving siswa pada saat pretes dan postes pada siswa kelas eksperimen. Dengan demikian hipotesis kerja penelitian ini diterima. Artinya implementasi model pedagogik multiliterasi berpengaruh secara signifikan terhadap kemampuan berpikir kritis dan problem solving siswa pada siswa kelas eksperimen.

\section{Uji Hipotesis Kedua}

Hipotesis kedua yang diuji dalam penelitian ini adalah model terlangsung berpengaruh secara signifikan terhadap kemampuan berpikir kritis dan problem solving siswa pada kelas kontrol. Berdasarkan hasil uji $t$ terhadap perbandingan nilai kemampuan berpikir kritis dan problem solving siswa di kelas kontrol diperoleh data sebagai berikut.
Tabel 4.2

Hasil Uji Perbandingan Nilai Kemampuan Berpikir Kritis Dan problem solving siswa antara Pretes dan Postes Kelas Kontrol

\begin{tabular}{|ll|r|}
\hline \multirow{2}{*}{} & & \multicolumn{1}{|c|}{ Pair 1 } \\
\cline { 3 - 3 } & & $\begin{array}{r}\text { Postes Kontrol - } \\
\text { Pretes Kontrol }\end{array}$ \\
\hline Paired & Mean & 11,22222 \\
& Std. Deviation & 11,88196 \\
& Std. Error Mean &, 99016 \\
& Interval of the & 9,26497 \\
& & \\
& & \\
& & 13,17947 \\
& & \\
& & 11,334 \\
& & 143 \\
\hline Df & &, 000 \\
\hline Sig. (2-tailed) & & \\
\hline
\end{tabular}

Berdasarkan tabel di atas dapat dikemukakan bahwa nilai t hitung sebesar 11,33. Besaran nilai Sig. (2-tailed) adalah 0,00. Ternyata nilai Sig. (2-tailed) lebih kecil dibanding taraf signifikasi (alfa) 0,05 . Hal ini berarti terdapat perbedaan antara nilai kemampuan berpikir kritis dan problem solving siswa pada saat pretes dan postes pada siswa kelas kontrol. Dengan demikian hipotesis kerja penelitian ini diterima. Artinya implementasi model terlangsung berpengaruh secara signifikan terhadap kemampuan berpikir kritis dan problem solving siswa pada siswa kelas kontrol.

\section{Uji Hipotesis Ketiga}

Sejalan dengan kenyataan bahwa model pedagogik multiliterasi maupun model terlangsung sama-sama mampu mengubah kemampuan berpikir kritis dan problem solving siswa siswa, perlu dilakukan perbandingkan kemampuan berpikir kritis dan problem solving siswa antara dua kelas. Guna meyakinkan bahwa kedua kelas yang dibandingkan memiliki kemampuan yang sama pada awal pembelajaran, sebelum melakukan pengujian perbedaan rerata postes perlu dilakukan pengujian rerata pretes antara

Pupun Nuryani, Yunus Abidin, Yusuf Tri Herlambang: [Model Pedagagik Multiliteraasi dalam Mengembangkan Keterampilan] 
kelas eksperimen dan kelas kontrol. Hasil pengujiannya adalah sebagai berikut.

Tabel 4.3

Hasil Uji Perbandingan Nilai Pretes Kemampuan Berpikir Kritis dan problem solving Siswa antara Kelas Eksperimen dan Kelas Kontrol

\begin{tabular}{|c|c|c|c|c|}
\hline & \multicolumn{2}{|c|}{ Pretes } \\
\hline & & & $\begin{array}{c}\text { Equal } \\
\text { variances } \\
\text { assumed }\end{array}$ & $\begin{array}{c}\text { Equal } \\
\text { variances } \\
\text { not } \\
\text { assumed }\end{array}$ \\
\hline $\begin{array}{l}\text { Levene's } \\
\text { Test for } \\
\text { Equality of } \\
\text { Variances }\end{array}$ & $\begin{array}{l}\text { F } \\
\text { Sig. }\end{array}$ & & $\begin{array}{l}\text {,388 } \\
, 534\end{array}$ & \\
\hline \multirow{7}{*}{$\begin{array}{l}\text { t-test for } \\
\text { Equality of } \\
\text { Means }\end{array}$} & $\mathrm{T}$ & & ,238 & ,238 \\
\hline & Df & & 286 & 285,353 \\
\hline & Sig. (2-taile & & ,812 & 812 \\
\hline & Mean Diffe & rence & ,35417 & ,35417 \\
\hline & $\begin{array}{l}\text { Std. Error } \\
\text { Difference }\end{array}$ & & 1,49054 & 1,49054 \\
\hline & $95 \%$ & Lower & $-2,57965$ & $-2,57967$ \\
\hline & $\begin{array}{l}\text { Confidenc } \\
\text { e Interval } \\
\text { of the } \\
\text { Difference }\end{array}$ & Upper & 3,28798 & 3,28801 \\
\hline
\end{tabular}

Berdasarkan tabel di atas dapat dikemukakan bahwa kedua data berdistribusi homogen dengan nilai $\mathrm{F}$ sebesar 0,38 dengan nilai signifikasi 0,53 yang lebih besar dari taraf nyata 0,05. Hasil perbandingan kemampuan pretes kemampuan berpikir kritis dan problem solving siswa antara kelas eksperimen dan kontol ditunjukkan dengan nilai $\mathrm{t}$ hitung sebesar 0,23. Besaran nilai Sig. (2-tailed) adalah 0,81. Ternyata nilai Sig. (2-tailed) lebih besar dibanding taraf signifikasi (alfa) 0,05. Hal ini berarti tidak terdapat perbedaan kemampuan berpikir kritis dan problem solving siswa pada saat pretes antara siswa di kelas eksperimen dan di kelas kontrol.

Sejalan dengan diketahuinya kesamaan kemampuan berpikir kritis dan problem solving siswa pada saat awal baik pada siswa kelas eksperimen maupun kelas kontrol, pengujian dilanjutkan dengan membandingkan perbedaan rerata kemampuan berpikir kritis dan problem solving siswa pada saat postes. Hasil pengujiannya adalah sebagai berikut.
Tabel 4.4

Hasil Uji Perbandingan Nilai Postes

Kemampuan berpikir kritis dan problem solving antara Kelas Eksperimen dan Kelas Kontrol

\begin{tabular}{|c|c|c|c|}
\hline & & \multicolumn{2}{|c|}{ Postes } \\
\hline & & $\begin{array}{c}\text { Equal } \\
\text { variances } \\
\text { assumed }\end{array}$ & $\begin{array}{c}\text { Equal } \\
\text { variances } \\
\text { not assumed }\end{array}$ \\
\hline $\begin{array}{l}\text { Levene's } \\
\text { Test for } \\
\text { Equality } \\
\text { of } \\
\text { Variances }\end{array}$ & $\begin{array}{l}\text { F } \\
\text { Sig. }\end{array}$ & $\begin{array}{r}2,094 \\
, 149\end{array}$ & \\
\hline t-test for & $\mathrm{T}$ & 7,171 & 7,171 \\
\hline Equality & Df & 286 & 281,767 \\
\hline of Means & Sig. (2-tailed) & ,000 &, 000 \\
\hline & $\begin{array}{l}\text { Mean } \\
\text { Difference }\end{array}$ & 8,93056 & 8,93056 \\
\hline & $\begin{array}{l}\text { Std. Error } \\
\text { Difference }\end{array}$ & 1,24538 & 1,24538 \\
\hline & 95\% Lower & 6,47929 & 6,47913 \\
\hline & $\begin{array}{l}\text { Confi Upper } \\
\text { dence } \\
\text { Interv } \\
\text { al of } \\
\text { the } \\
\text { Differ } \\
\text { ence }\end{array}$ & 11,38183 & 11,38198 \\
\hline
\end{tabular}

Berdasarkan tabel di atas dapat dikemukakan bahwa kedua data berdistribusi tidak homogen dengan nilai $\mathrm{F}$ sebesar 2,09 dengan nilai signifikasi 0,149 yang lebih kecil dari taraf nyata 0,05 . Hasil perbandingan kemampuan postes kemampuan berpikir kritis dan problem solving antara kelas eksperimen dan kontol ditunjukkan dengan nilai $t$ hitung sebesar 7,17. Besaran nilai Sig. (2-tailed) adalah 0,00. Ternyata nilai Sig. (2-tailed) lebih kecil dibanding taraf signifikasi (alfa) 0,05 . Hal ini berarti terdapat perbedaan kemampuan berpikir kritis dan problem solving pada saat postes antara siswa di kelas eksperimen dan di kelas kontrol. Hal ini berarti bahwa hipotesis kerja penelitian ini diterima artinya implementasi model pedagogik multiliterasi berpengaruh secara signifikan terhadap kemampuan berpikir kritis dan problem solving siswa sekolah dasar.

\section{Pembahasan}

Penelitian ini diawali dengan gagasan perlunya konsep pendidikan yang 
berorientasi pada upaya dalam mengembangkan kompetensi abad ke-21, khususnya keterampilan berpikir tingkat tinggi yang meliputi: berpikir kritis, problem solving, kreatif dan metakognisi pada jenjang sekolah dasar di Indonesia. Berdasarkan hal tersebut, pedagogik Multiliterasi menjadi salah satu konsep pendidikan (teoretis-praksis) yang telah terbukti menjadi konsep pendidikan yang dapat mengembangkan keterampilan berpikir abad ke-21.

Berkaitan dengan hal di atas, secara terminologi, pada awalnya multiliterasi hanya dikenal dengan istilah literasi yakni alat yang dapat digunakan untuk beroleh dan mengomunikasikan informasi. Sejalan dengan perkembangan zaman, istilah ini terus berkembang menurut bidang ilmu tertentu dan dalam perkembangan terakhirnya bersinergi dengan kemajuan teknologi informasi dan komunikasi sehingga terbentuklah istilah multiliterasi. Cope dan Kalantzis (2005) sebagai penggagas awal istilah ini menyatakan bahwa penggunaan istilah multiliterasi didasarkan atas dua argumen yang erat hubungannya dengan budaya, institusi pendidikan, dan tuntutan global. Alasan pertama istilah digunakan adalah bahwa dalam mengomunikasikan informasi dapat digunakan beragam media dan alasan kedua adalah bahwa istilah ini memiliki arti yang sangat penting dalam meningkatkan arti penting bahasa dan budaya bagi perkembangan kapabilitas seseorang. Dengan demikian, pendidikan multiliterasi memiliki beragam fokus penggunaan bahasa yang akan sangat bergantung pada bidang ilmu yang dibahas, konteks budaya yang memengaruhinya, serta efek sosial yang dihasilkannya.

Bertemali dengan konsep pendidikan multiliterasi di atas, dalam perkembangan lebih lanjut Morocco, dkk. (2008, hlm. 10) menyatakan bahwa keterampilan-keterampilan multiliterasi yang harus dikuasai agar mampu mendukung dan mengembangkan kompetensi abad ke-21 meliputi keterampilan membaca pemahaman mendalam, keterampilan menulis yang baik untuk membangun dan mengekspresikan makna, keterampilan berbicara secara akuntabel, dan keterampilan mengusai berbagai media digital dalam kaitannya dengan berbagai bidang ilmu. Pendapat ini senada dengan konsep Bianco (2000) yang menyatakan bahwa tujuan pendidikan multiliterasi adalah untuk membentuk kemampuan siswa dalam hal memahami semakin kompleksnya bahasa dan kode keaksaraan; meningkatkan kemampuan siswa untuk menggunakan berbagai kode-kode mode bahasa yang digunakan; dan meningkatkan kemampuan siswa untuk memahami dan menghasilkan makna secara lebih kaya dan lebih rumit sebagai dampak diintegrasikannya bahasa dengan beragam budaya dan beragam ilmu pengetahuan (multibudaya, multimodal, dan multibahasa).

Konsep pendidikan multiliterasi juga dikemukakan oleh ahli lain yakni McKee dan Ogle (2005). McKee dan Ogle (2005) memandang guna memberikan pengertian tentang pendidikan multiliterasi, literasi pada awalnya harus dipandang sebagai kemampuan untuk menggunakan membaca, menulis, menyimak, dan berbicara seefisien mungkin untuk meningkatkan kemampuan berpikir dan berkomunikasi. Selanjutnya definisi ini diperluas dengan kemampuan mengkritisi, menganalisis, dan mengevaluasi informasi dari berbagai sumber dalam berbagai ragam disiplin ilmu (Pullen dan Cole, 2010). Pendapat ini sejalan dengan Ivanic (2009) yang menyatakan bahwa pendidikan multiliterasi merupakan proses memberikan tantangan kepada siswa untuk mengkaji dan menerapkan literasi praktis yang berfungsi sebagai alat mediasi untuk mempelajari berbagai konsep lintas kurikulum.

Sejalan dengan uraian di atas, pendidikan multiliterasi dapat 
didefinisikan sebagai model pendidikan yang mengoptimalkan keterampilanketerampilan multiliterasi dalam mewujudkan situasi pembelajaran saintifik. Pembelajaran ini diorientasikan bagi pengembangan dan penggunaan keempat kompetensi abad ke-21 yakni kompetensi berpikir kritis, kompetensi pemahaman konseptual, kompetensi kolaboratif dan komunikatif, dan kompetensi berpikir kreatif. Keterampilanketerampilan yang digunakan guna mendukung keempat kompetensi tersebut adalah keterampilan membaca, keterampilan menulis, keterampilan berbicara, dan keterampilan penguasaan media informasi dan komunikasi (Abidin,dkk., 2015).

Berpijak pada hal di atas, penelitian ini telah membuktikan bahwa penerapan model pedagogik multiliterasi telah terbukti secara efektif meningkatkan kemampuan berpikir tinggi siswa sekolah dasar, khususnya keterampilan berpikir kritis dan problem solving. Hal ini didasarkan pada hasil perbandingan kemampuan postes kemampuan berpikir kritis dan problem solving antara kelas eksperimen dan kontol ditunjukkan dengan nilai t hitung sebesar 7,17 . Besaran nilai Sig. (2-tailed) adalah 0,00 . Ternyata nilai Sig. (2-tailed) lebih kecil dibanding taraf signifikasi (alfa) 0,05. Hal ini berarti terdapat perbedaan kemampuan berpikir kritis dan problem solving pada saat postes antara siswa di kelas eksperimen dan di kelas kontrol. Hal ini berarti bahwa hipotesis kerja penelitian ini diterima artinya implementasi model pedagogik multiliterasi berpengaruh secara signifikan terhadap kemampuan berpikir kritis dan problem solving siswa sekolah dasar.

Keberhasilan penelitian ini sejalan dengan berbagai upaya mengimplementasikan konsep pendidikan multiliterasi yang telah banyak dilakukan melalui beragam penelitian baik secara parsial maupun secara utuh mengkaji berbagai dimensi pendidikan multiliterasi. Penelitian secara parsial berarti para peneliti hanya mengkaji salah satu dimensi pendidikan multiliterasi baik dalam dimensi teori pedagogis, dimensi pembelajaran, dimensi bahan ajar, maupun dimensi evaluasi. Namun belum menyentuh pada tataran dimensi manusia yang salah satu diantaranya adalah dimensi sosio-kultural sebagai bagian dari struktur fundamental pengembangan pendidikan yang berorientasi pada upaya dalam mengembangkan kompetensi abad ke-21 pada siswa sekolah dasar.

Berdasarkan hasil penelitian yang telah dilakukan, keberhasilan penelitian ini sejalan dengan penelitian secara parsial terhadap konsep pendidikan multiliterasi salah satunya dilakukan oleh Cope dan Kalantzis (2005) yang menghasilkan model pedagogik multiliterasi yakni sebuah desain pedagogis yang terdiri atas 4 komponen penting mencakup situasi praktis, pembelajaran sistematis, bingkai kritis, dan transformasi praktis yang terbukti mampu meningkatkan kemampuan berpikir kritis dan problem solving siswa.

Sejalan dengan kenyataan bahwa lingkup penelitian ini masih terbatas di sekolah penjajakan, perlu penelitian dengan subjek yang lebih luas. Oleh sebab itu, pada penelitian tahun berikutnya akan dilakukan penerapan model pedagogik multiliterasi pada dengan membangun sekolah percontohan dengan subjek penelitian yang lebih banyak. Melalui penerapan model pedagogik multiliterasi pada sekolah percobaan diharapkan variasi pola penerapan model pedagogik multiliterasi juga lebih bervariasi dan diperoleh gambaran hasil yang lebih komprehensif.

Berkaitan dengan hal di atas, upaya pengembangan penelitian selanjutnya akan dilakukan pada subjek lebih luas melalui pendekatan multibudaya pada objek wilayah yang memiliki karakteristik yang heterogen. Hal ini bertujuan untuk menggali unsur-unsur filosofis pada setiap objek yang diharapkan mampu menjadi unsur/ nilai filosofis untuk membangun 
struktur fundamental pengembangan model pedagogik multiliterasi.

Selain itu, secara argumentatif hal ini didasarkan pada kenyataan bahwa pengembangan konsep pendidikan selama ini masih bersifat parsialistik, dan belum mampu mengakomodasi perbedaan yang merupakan keniscayaan, baik itu karakter dan latar belakang budaya siswa. Oleh sebab itu, pedagogik multiliterasi merupakan jawaban atas kebutuhan pendidikan dewasa ini, khususnya di abad ke-21 dan dalam konteks ke-Indonesiaan.

\section{KESIMPULAN}

Berdasarkan hasil penelitian dan analisis data hasil penelitian, penelitian ini menyimpulkan beberapa simpulan tentang beberapa hal esensial dalam pedagogik multiliterasi yaitu bahwa pola-pola implementasi Pedagogik multiliterasi meliputi: Sosial budaya, pembelajaran multiliterasi, bingkai berpikir dan transformasi praktis. Selain itu, adapun implementasi model Pedagogik multiliterasi telah terbukti berpengaruh secara signifikan terhadap kemampuan berpikir kritis dan problem solving pada siswa kelas eksperimen. Hal ini menandakan bahwa model pedagogik multiliterasi mampu meningkatkan kemampuan berpikir kritis dan problem solving siswa pada jenjang sekolah dasar secara efektif pada berbagai bidang kajian yang diajarkan.

Implementasi model Pedagogik multiliterasi terlangsung berpengaruh secara signifikan terhadap kemampuan model Pedagogik multiliterasi pada siswa kelas kontrol. Hal ini menandakan bahwa model terlangsung juga sebenarnya telah mampu meningkatkan kemampuan berpikir kritis dan problem solving siswa pada jenjang sekolah dasar secara efektif pada berbagai bidang kajian yang diajarkan.

Implementasi model pedagogik multiliterasi telah terbukti lebih baik dalam meningkatkan kemampuan berpikir kritis dan problem solving siswa jika dibandingkan dengan model terlangsung yang biasanya digunakan di sekolah. Hal ini menandakan bahwa model pedagogik multiliterasi lebih mampu meningkatkan kemampuan berpikir kritis dan problem solving siswa pada jenjang sekolah dasar secara efektif pada berbagai bidang kajian yang diajarkan dibandingkan dengan model terlangsung yang biasanya digunakan di sekolah dasar.

Berdasarkan simpulan di atas, adapun penelitian ini mengajukan beberapa saran bahwa Pedagogik multiliterasi lebih efektif dalam meningkatkan kemampuan berpikir kritis dan problem solving siswa sekolah dasar dibandingkan dengan model terlangsung, sekolah disarankan mengimplementasikan model pedagogik multiliterasi dalam praksis kegiatan pembelajaran. Selain itu, penerapan model pedagogik multiliterasi harus didukung oleh kerja sama seluruh elemen, baik antara guru, pihak manajemen sekolah, dan orang tua. Hal ini perlu dilakukan agar terwujudnya efektivitas pembelajaran yang bermutu, sehingga memberi implikasi pada berkembangnya potensi siswa.

\section{DAFTAR PUSTAKA}

Abidin, Y., Mulyati, T., Yunansah, H. (2015). Pembelajaran Literasi dalam konteks Pendidikan Multiterasi Integratif, dan Berdiferensiasi. Bandung: Rizqy Press.

Al Muchtar, S. (2001). Pendidikan \& Masalah Sosial Budaya. Bandung: Gelar Pustaka Mandiri.

Azzet, A H. (2011) Pendidikan yang membebaskan. Yogyakarta: ArRuzz Media.

Bianco, J.L. (2000). "Multiliteracies and Multilingualism" dalam Multiliteracies: Literacy Learning and the Design of Social Futures. New York: Routledge.

Cope, B. dan Kalantzis, M. (2005). Multiliteracies: Literacy Learning and the Design of Social Futures. New York: Routledge.

Pupun Nuryani, Yunus Abidin, Yusuf Tri Herlambang: [Model Pedagagik Multiliteraasi dalam Mengembangkan Keterampilan] 
Cresswell, J.W.(2007). Mixed Method. London: Sage Publicational.

Dewantara, (2011). Kebudayaan.

Yogyakarta: Yayasan Persatuan Tamansiswa.

Freire, P. (2008). Pendidikan Kaum tertindas. Jakarta: Pustaka LP3S Indonesia.

Hasbullah. (2008). Dasar-Dasar Ilmu Pendidikan. Jakarta: PT Raja Grafindo Persada.

Herlambang, Y T, (2018). Pedagogik: Telaah Kritis Ilmu Pendidikan Dalam Multiperspektif. Jakarta: Bumi Aksara.

Ivanic, R. (2009). "Bringing Literacy Studies into Research and Prospects" dalam The Future of Literacy Studies. New York: Palgrave MacMillan.

McKee, J. \& Ogle, D. (2005). Integrating Instruction: Literacy and Science. Tools for Teaching Literacy Series. Guilford Publications.

Morocco, C.C., et al. (2008). Supported Literacy for Adolescents: Transforming Teaching and Content Learning for The TwentyFirst Century. San Francisco: Jossey-Bass A Wiley Imprint.

Pullen, D.L. dan Cole, D.R. (2010). Multiliteracies and Technology Enhanced Education: Social Practice and the Global Classroom. New York: Information Science Reference.

Tilaar, H.A.R, (2002) Pendidikan, Kebudayaan, dan masyarakat madani Indonesia. Jakarta: Rineka Cipta.

Tilaar, H.A.R. (2009). Kekuasaan dan Pendidikan: Manajemen Pendidikan Nasional Dalam Pusaran Kekuasaan. Jakarta: Rineka Cipta.

Tilaar, H.A.R. (2012). Perubahan Sosial dan Pendidikan: Pedagogik Transformatif untuk Indonesia. Jakarta: Rineka Cipta.
Tilaar, H.A.R. (2015). Pedagogik teoretis untuk Indonesia. Jakarta: Kompas. 